\title{
A new Zanclognatha from eastern North America and a preliminary key to the larvae of the genus (Lepidoptera, Erebidae, Herminiinae)
}

\author{
David L. Wagner ${ }^{1, \dagger}$, Timothy L. McCabe $e^{2, \ddagger}$ \\ I Department of Ecology and Evolutionary Biology, University of Connecticut, Storrs, Connecticut 06269 \\ 2 New York State Museum, Albany, New York, 12230 \\ † urn:lsid:zoobank.org:author:9AC6850B-C5A0-456C-8F34-06FF6C322AAB \\ †urn:lsid:zoobank.org:author:85C75EE9-6372-477D-A227-E875BE210A35 \\ Corresponding author: David L. Wagner (david.wagner@uconn.edu)
}

Academic editor: D. Lafontaine | Received 21 June 2011 | Accepted 4 November 2011 | Published 24 November 2011 urn:lsid:zoobank.org:pub:F5BBAB2B-DB88-4C16-AEC8-EB4E653AFFAE

Citation: Wagner DL, McCabe TL (2011) A new Zanclognatha from eastern North America and a preliminary key to the larvae of the genus (Lepidoptera, Erebidae, Herminiinae). In: Schmidt BC, Lafontaine JD (Eds) Contributions to the systematics of New World macro-moths III. ZooKeys 149: 89-101. doi: 10.3897/zookeys.149.2348

\begin{abstract}
The adult of a widespread but previously undescribed species of Zanclognatha Lederer is described from eastern North America. Images of the mature larva and life history data for Zanclognatha dentata sp. n. are included, along with a preliminary key to the larvae of ten eastern North American Zanclognatha species.
\end{abstract}

\section{Keywords}

detritus feeding, Herminiinae, larvae, Zanclognatha, species radiation

\section{Introduction}

More than a dozen species of Zanclognatha Lederer, 1857 occur in eastern North America, often with six or more species flying at a single location. Alpha diversity and abundance of Zanclognatha tend to be highest in mixed hardwood and conifer woodlands and forests with an accumulation of leaf litter. The Nearctic Zanclognatha fauna

Copyright D.L.Wagner, T.L. McCabe. This is an open access article distributed under the terms of the Creative Commons Attribution License, which permits unrestricted use, distribution, and reproduction in any medium, provided the original author and source are credited. 
bears earmarks of a recent radiation: several species are weakly differentiated or confused (e.g., Z. gypsalis-minoralis-theralis complex; genitalic diversity across the genus is modest in both sexes; and some species-level taxa occur mainly north of recent glacial maxima, e.g., $Z$. lutalba (Smith, 1906). In addition to the new species described here, which has long been confused with $Z$. protumnusalis (Walker, 1859), additional eastern Zanclognatha await recognition, e.g., the undescribed species near $Z$. lituralis (Hübner, 1818) mentioned by Rings et al. (1992).

The most recent revisionary study of Zanclognatha and its relatives is that of Owada (1987) based on his studies of the diverse Japanese herminiine fauna. In addition to Zanclognatha, his treatment includes all allied genera. Owada recognized both Zanclognatha and Polypogon Schrank (1802) as valid, with the former genus defined by having the labial palpus sickle-shaped and upcurved over the vertex; male antenna with a knot; M2, M3, and CuA1 not stalked in the forewing; hindwing with cell extending to nearly $1 / 2$ and M2 arising from above the anal angle (of cell); male foreleg with tibial sheath; and male foretarsus five-segmented with first segment lacking a projection. Zanclognatha dentata sp. n., sharing the above features, falls unambiguously within Owada's concept of the genus, despite the fact that the male genitalia of $Z$. dentata and other Nearctic members of the genus Zanclognatha, superficially resemble those of Polypogon tentacularia (L.), the type of Polypogon, in possessing a deeply emarginate valve with two primary lobes. The type-species of Zanclognatha, Z. lunalis Scopoli, and its Palearctic relatives, have a valve that is comprised of three lobes. Starting with Smith (1895), Lederer's Zanclognatha has been used for the Nearctic herminiines with an antennal knot and upcurved labial palpus. Poole (1989) transferred North American Zanclognatha into Polypogon, but later, moved all species back into Zanclognatha (Poole and Lewis 1996).

The new species was "discovered" while reviewing larval images of $Z$. protumnusalis and $Z$. martha Barnes, 1928. Larval images indicated that there were three species involved (see Figs $8-11$ and key). Below we describe the adult, provide images of the last instar, and discuss the biology of $Z$. dentata sp. n. We also include a key to the larvae of ten species of Zanclognatha found in eastern North American.

\section{Methods and materials}

A cohort of larvae was reared from a female collected by Dale F. Schweitzer from New Jersey, Atlanta County: Egg Harbor Township, Absecon Creek on 15 July 2002, DLW Lot Number 2002G117. Larvae were reared on dead, browned, lightly moistened oak leaves. Surface as well as partially decayed leaves were provided (see Hohn and Wagner 2000). Specimens were examined from the collections listed below. In addition, several colleagues sent records, images, and observations from personal collections (see acknowledgments). We checked European and Asian literature to ascertain if $Z$. dentata might represent an Old World species. Larval images (both film and digital) have been deposited at the University of Connecticut. We prepared 29 genitalic dissections 
of Zanclognatha: 12 of the dentata-martha-protumnusalis group (5 females, 7 males) and 17 dissections of five other species for comparison. In addition we examined 19 Zanclognatha genitalic preparations in Cornell University's insect collection. Martin Honey and Don Lafontaine secured images of the types of Zanclognatha protumnusalis and $Z$. minimalis Grote in the British Museum.

AMNH American Museum of Natural History, New York, New York, USA

BMNH Natural History Museum, London, England UK

CAES Connecticut Agricultural Experiment Station, New Haven, Connecticut, USA

DH Personal collection of Daniel Handfield, Saint-Mathieu de Beloeil, Québec, Canada

NYSM New York State Museum, Albany, New York, USA

PMNH Peabody Museum, Yale University, New Haven, Connecticut, USA

TLM Personal collection of Timothy McCabe, Albany, New York, USA

UCMS University of Connecticut, Storrs, Connecticut, USA

\section{Systematics}

Zanclognatha dentata Wagner \& McCabe, sp. n.

urn:lsid:zoobank.org:act:6C1EC0E9-2F9A-4A6B-AC61-7F712FC6C9B8

http://species-id.net/wiki/Zanclognatha_dentata

Figs 1-9

Type material. Holotype male (Fig. 1): USA, Connecticut, Tolland Co., Mansfield, Hunters Run, $41^{\circ} 46.18^{\prime} \mathrm{N}, 72^{\circ} 14.87^{\prime} \mathrm{W}$, 4 July 2008 , D. L. Wagner, mercury vapor light; DNA barcode voucher \# CNCLEP 81920 (UCMS). Paratypes 54 males, 43 females. Connecticut: Litchfield County, Norfolk Great Mountain Forest, 13 July 1997, D. L. Wagner, (1 つ’) (UCMS) \& 12 July 2008, D. L. Wagner, N. Proctor, A. Meleg (1 ठ) (UCMS); Middlesex County, East Haddam, Devil's Hopyard State Park, larvae 11 May 1994, 18 June, 1995, 20 June 1999, J. Fengler, J. Lozier, beaten from Tsuga canadensis $(3$ 今) (CAES); New London County, Griswold, Hopeville Pond State Park, 9 July 1996,

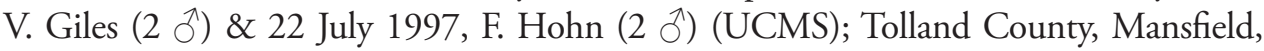

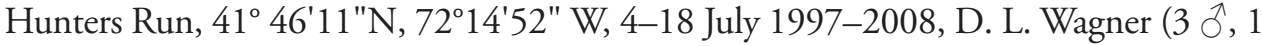

ㅇ) (UCMS); Windham County, Hampton, 2 July 1984, D. L. Wagner (1 O $\left.{ }^{\top}\right)$ (UCMS); Hampton Reservoir, NW of bog, 25-26 July 1996, D. L. Wagner \& B. D. Williams (1 ㅇ) (UCMS); Catden Swamp, 25-26 July 1996, D. L. Wagner \& B. D. Williams (1 9 ) (UCMS); Sterling Junction Rt. 14/14A, larva 30 June 2007, D. L. Wagner, beaten from and reared on Lonicera merrowii, emerged 18 July 2007, DLW Lot 2007F90.1 (1 P) (UCMS). Maine: Oxford County, Magalloway Plantation, State Route 16, $3 \mathrm{~km}$ NNE New Hampshire stateline, larva 5 June 1995, C. T. Maier, beaten from Abies balsamea $(1$ ㄱ) (CAES). Massachusetts: Franklin County, Montague Plain, 11 July 1991, D. L. 

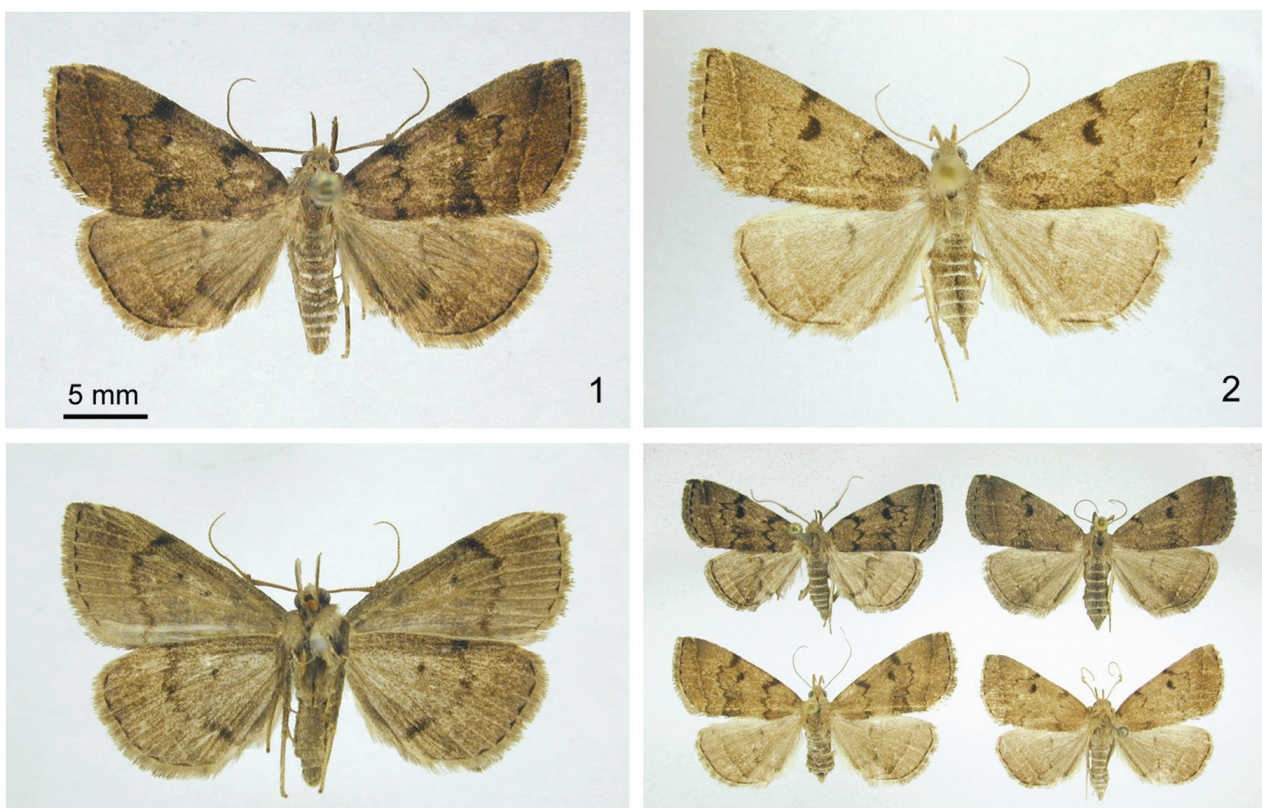

3

Figures I-4. Zanclognatha dentata sp. n. I Holotype male, dorsal. CT: Tolland Co., Mansfield 2 Female, dorsal. CT: Windham Co., Hampton Reservoir 3 Holotype male, ventral 4 Variation. NJ: Atlantic Co., Egg Harbor Township (upper left); CT: Windham Co., Sterling (upper right); CT: Windham Co., Hampton Reservoir (lower left); MA: Franklin Co., Montague, Plains Road (lower right).

Wagner, P. Z. Goldstein, \& S. McKamey (1 ð̊) (UCMS); Middlesex County, Concord, H.D. Thoreau's gravesite, 3-4 July 2009, D. L. Wagner (1 đ̂) (UCMS). Michigan: Cheboygan Co., Pellston, Biological Douglas Lake, 7 July 2007, D. L. Wagner ( 1 Ô) (UCMS). New Jersey: Atlanta County, Egg Harbor Township, Absecon Creek, female 15 July 2002, D. F. Schweitzer, reared on dead oak leaves, emerged 13 Sept. 2002, DLW Lot 2002G117 (1 ふ) (UCMS); Atlantic County, Pomona, 6 July 1991, D. F. Schweitzer $(1$ đ) $)$, gen. slide McCabe 2924 (TLM); Burlington County, Junction Route 563 \& Wading River, 2 June 1999, D. L. Wagner, B. D. William, M. A. Volovski, \& P. Mallard (1 đ) (UCMS). New Hampshire: Coos County, Concord, 1 km NNE, North Concord, larva 4 June 1995, C. T. Maier, beaten from Abies balsamea, (1 Ỏ) (CAES); Pittsburg, Ildewide, west side of Second Connecticut Lake, larva 11 June 1996, C. T. Maier, beaten

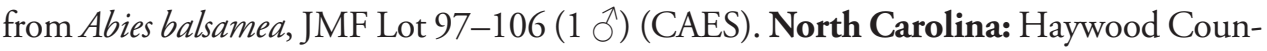
ty, Cataloochee Campground, larva 10 June 2002, D. L. Wagner, beaten from Hamamelis virginiana, emerged 3 Aug. 2002, DLW Lot 2002E83 (1 +) (UCMS). New York: Albany Co., Pine Bush, 42 43.05' N, 73 52.16' W, 100 m, 2 July - 6 Aug. 1987-1997, T. McCabe (7 Oे 3 ㅇ) (NYSM, TLM); Clinton Co., Gadway Barrens, $44^{\circ} 56.59^{\prime} \mathrm{N}$ 7345.17'W, 180 m, 2 Aug. 1997, T. McCabe (2 +) (TLM); Essex Co., Lake Stevens,

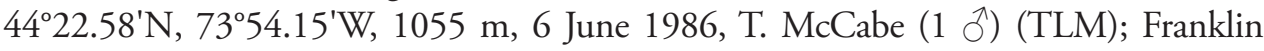
Co., Bloomingdale bog, $44^{\circ} 24.36^{\prime} \mathrm{N}, 74^{\circ} 07.24^{\prime} \mathrm{W}, 475 \mathrm{~m}, 2$ Aug. 1997, T. McCabe (4 
9), gen. slide McCabe 4188 \& 4186 (NYSM, TLM); Hamilton Co., 6 mi. E. Indian

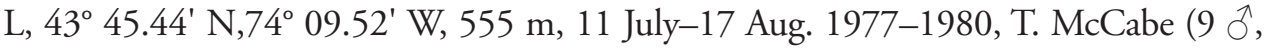
6 9) (NYSM); Hamilton Co., 6 mi. E. Indian L, 4345.44'N, 7409.52'W, 555 m, 13 July 1977, T. McCabe (1 , 1 đ), gen. slide McCabe 1279 (NYSM); Orange Co., Cedar

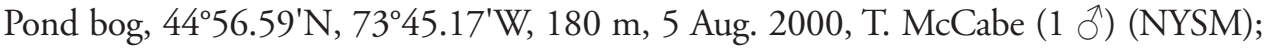
Ulster Co., Lake Awosting, 41 $42.43^{\prime}$ N, 74 16.58' W, 550 m, 6 Aug. 1906, T. McCabe

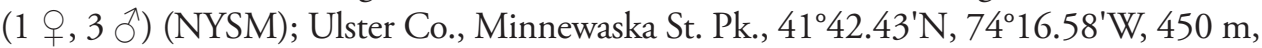
6 Aug. 1906, T. McCabe (1 गै) (NYSM). Québec: Val-Limoges, 200 km north of Ottawa, 46 39.8' N, 7545.1'W, 14 July 2004, D. Handfield (2 9) (DH); La Présentation, $30 \mathrm{~km}$ east of Montréal, $45^{\circ} 41.3^{\prime} \mathrm{N}, 73^{\circ} 05.3^{\prime} \mathrm{W}, 30$ June 2006, D. Handfield $\left(2 \jmath^{\top}, 4\right.$ ㅇ) (DH); Sainte-Christine, $65 \mathrm{~km}$ east of Montréal, $45^{\circ} 39.0^{\prime} \mathrm{N}, 72^{\circ} 26.8^{\prime} \mathrm{W}, 3$ July 2006, 20 July 2006, 28 July 2006, D. Handfield (2 今, 4 9) (DH); Villeroy, 175 km northeast of Montreal, $46^{\circ} 22.7^{\prime} \mathrm{N}, 71^{\circ} 49.9^{\prime} \mathrm{W}, 7$ July 2006, D. Handfield (2 ठ̂̉) (DH); Saint-Narcisse, $200 \mathrm{~km}$ north-east of Montreal, 46 35.1' N, 73 11.9' W, 13 July 2006,

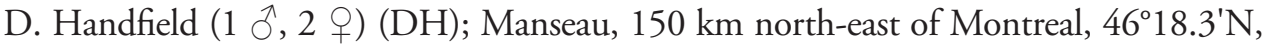
$72^{\circ} 00.7^{\prime} \mathrm{W}, 24$ July 2006, D. Handfield (3 Ĵ, 9 q) (DH). Vermont: Essex County, Victory, Victory State Forest, $2.5 \mathrm{~km} \mathrm{SW} \mathrm{Granby,} \mathrm{larva} 10$ June 1997, C. T. Maier, on Abies balsamea (1 q) (CAES); Windham Co., Marlboro, Banks Road, 489 m, larva 15 June 1994, C. Lemmon, on Abies balsamea, Chris Maier Lot 94-89 (1 §, 1 9) (CAES).

Etymology. The species name derives from the toothed antemedial and medial lines on the forewing.

Diagnosis (habitus). Dark tooth-like spots along costa, marking beginning of antemedial and postmedial lines, distinguish Z. dentata from all but $Z$. lituralis, $Z$. martha, and some $Z$. protumnusalis. The presence of a third (subapical) costal spot, (where the subterminal line meets the costa), usually present in $Z$. lituralis, is absent in $Z$. dentata; the grayer ground color and uneven subterminal line also distinguish $Z$. lituralis from $Z$. dentata. $Z$. martha is distinguished from $Z$. dentata by its darker ground color, weakened subterminal line, darkened distal $1 / 4$ of forewing, and its larger size. The discal spot of $Z$. dentata tends to be larger, more vertically elongate, and the distal side is often more concave than that of $Z$. protumnusalis and others. The antemedial line of $Z$. dentata is more toothed (zigzagged) than that of most other similarly-sized, brown North American Zanclognatha (but see discussion). The postmedial line is often abruptly-angled outward over the radial veins in $Z$. dentata, whereas in $Z$. protumnusalis and $Z$. martha, this part of the postmedial tends to be more evenly rounded. In $Z$. protumnusalis the subterminal line is more likely to be outwardly edged with pale scales (in both wings) and $Z$. protumnusalis tends to have more tan in the ground color, thinner and crisper costal spots, and lacks the blurry patch of fuscous scales basad of the postmedial line, which extends from the inner margin to the cell, that is present in many $Z$. dentata. In most specimens of $Z$. protumnusalis the ground color of the hindwings tends to be noticeably paler than that of the forewings, especially through the radial area.

Diagnosis (genitalia). (Figs 5-7). Male genitalia of $Z$. dentata differ significantly from those of $Z$. lituralis - most notably $Z$. dentata has the upper process of the valve 

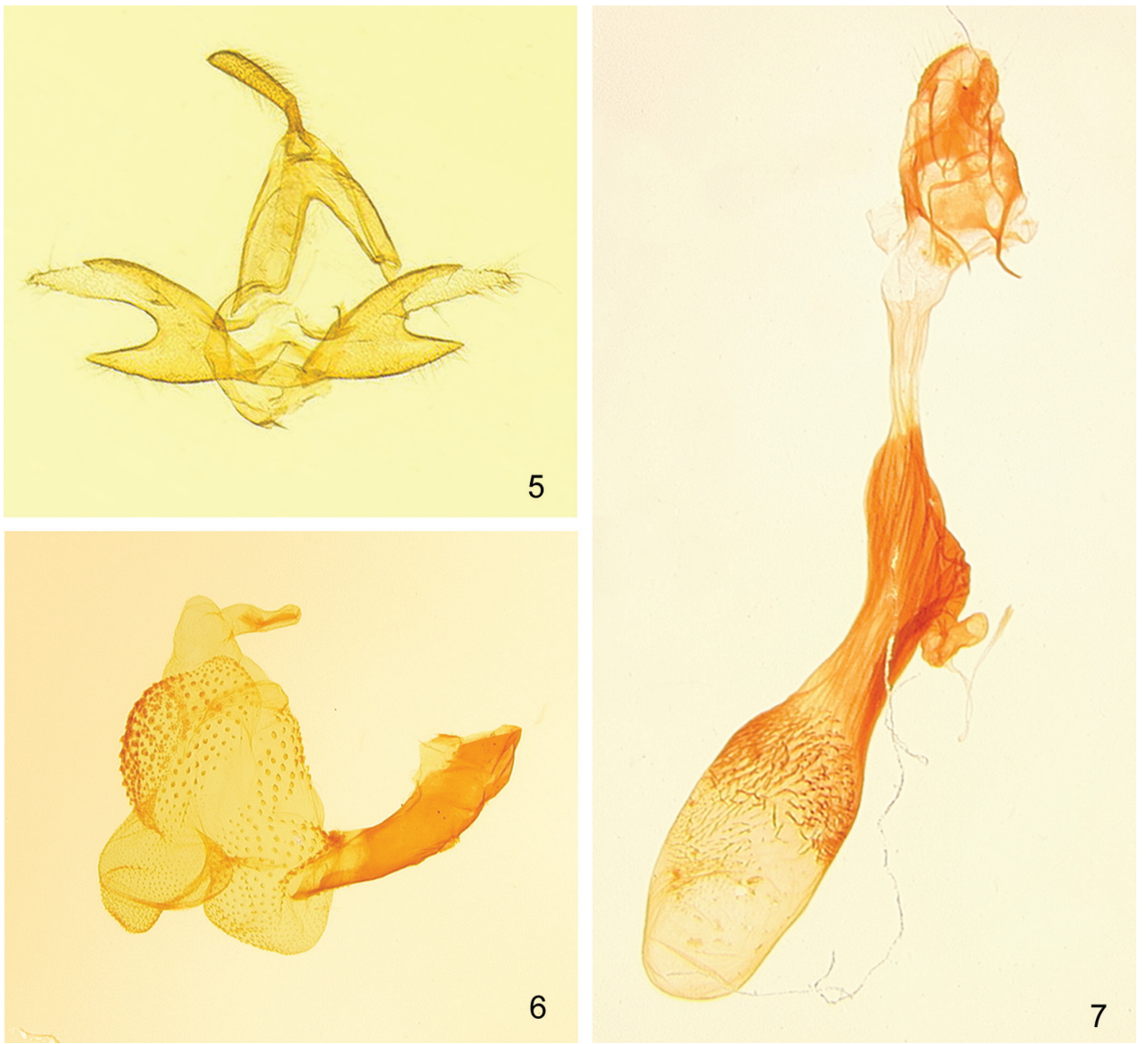

Figures 5-7. Zanclognatha dentata sp. n. genitalia. 5 male, NY: Hamilton Co., Indian Lake, McCabe diss. no. 1279. $\mathbf{6}$ aedeagus, same data. $\mathbf{7}$ female, NY: Franklin Co., Bloomingdale bog, McCabe diss. no. 4188 .

adorned with a small tooth, which is only half as long as the width of the costal lobe, whereas $Z$. lituralis has a large tooth that is as long as the costal lobe is wide. $Z$. lituralis has a valve that resists spreading during genitalic preparation and becomes badly skewed if forced. $Z$. martha resembles $Z$. dentata but is larger. The spread valves of $Z$. martha expand to $3.0 \mathrm{~mm}$ whereas those of $Z$. dentata expand to $2.7 \mathrm{~mm}$. $Z$. dentata male genitalia appear indistinguishable from those of $Z$. protumnusalis to our eye. Female genitalia have similar internal spinules in the corpus bursa in $Z$. dentata, $Z$. lituralis, $Z$. martha, and $Z$. protumnusalis, but these extend farther on one side of the bursa in $Z$. protumnusalis and $Z$. dentata. In our dissections, length of the female genitalia in $Z$. dentata is $\geq 6 \mathrm{~mm}$ in total length, whereas those of $Z$. protumnusalis length measure circa $5 \mathrm{~mm}$.

Description. Male. Forewing length: FWL $10.5-13 \mathrm{~mm}(\mathrm{n}=30)$. Head - pale to deep brown with forward projecting tufts from vertex. Antenna with male androconial notch at $1 / 3$. Labial palpus with third segment $1 / 2$ length of second, with pale scales at apex; second segment with pale scales over mesal surface. Thorax - dorsum 
concolorous with head. Forewing subtriangular, pale to chocolate brown, and usually well marked. Antemedial line toothed or scalloped; discal spot usually well developed sometimes with distal side concave; postmedial line toothed, thickened where it joins costa; often with diffuse medial patch of dark scales from inner margin to cell; subterminal line straight, sparsely edged outwardly with pale scales. Hindwing brown with weak discal spot and variously-developed postmedial and subterminal lines; the latter generally poorly differentiated to absent. If outwardly edged with pale scales, usually only over anal and cubital areas of wing. Underside of both wings usually with discal spot and well-expressed postmedial line. Procoxa elongate with yellow androconia. Profemur with (concealed) yellow hair pencil from distal end and fan of dark androconial scales from proximal end-both of which usually folded and covered by broad hood of chocolate colored scales from protibiae. Mesothoracic and metathoracic tibiae and tarsomeres lightened apically, appearing banded in dark individuals. Abdomen - Tan to brown with distal edge of each segment pale: abdomen appearing banded in well-marked individuals. Male genitalia (Figs 5, 6). Valves (Fig. 5) - Nearly symmetrical; uncus distally expanded compressed laterally, terminating in minute tooth; tegumen as long as valve; valve divided into two lobes for half its length; costal (upper) lobe with short mesal tooth halfway along length; costal lobe terminating in irregular apex crowned with setae, with apices of left and right valves differing in detail; lower lobe unadorned. Aedeagus (Fig. 6) - everted vesica covered with spinules; simple basal lobe; slightly curved mesal lobe; large distal lobe supports very small bulge without spicules. Female genitalia (Fig. 7) - Papillae anales unmodified, short; anterior and posterior apophyses subequal in length; distal half of ductus bursae lightly sclerotized, then heavily sclerotized and ribbed to beyond ductus seminalis; ductus seminalis short and twisted; caudal half of corpus bursae with relatively long, curved, internal spinules; spinules extend past middle of corpus bursae on side opposite ductus seminalis.

Remarks. Dark, boldly-marked individuals are commonly encountered southward. In some, the medial patch of dark scales extends across the wing. Adult phenotypes overlap with those of $Z$. protumnusalis to the extent that we cannot reliably assign about $15 \%$ of light-trapped adults to one species or the other. No diagnostic genitalic characters are known for either sex. COI barcodes for those individuals that we could reliably identify were diagnostic (see below). The holotype was submitted to BOLD for COI barcoding (CNCLEP 81920) and its sequence will be submitted to GenBank. Larval features are also diagnostic (for both species).

Distribution. So far as known, Ontario to Nova Scotia southward through the Great Lake states and in the Appalachians to northern Georgia. One moth from a sandhills area in central South Carolina appears to represent $Z$. dentata ${ }_{s}$ but we exclude the moth from the type series.

Biology. Adults have been taken at lights and sugar bait from a broad range of habitats that includes bogs, swamps, marshes, Atlantic white cedar swamps, swales, and other wetlands, mesic hardwood and Appalachian cove forests, a variety of boreal (conifer) forest types, and pitch pine/scrub oak barrens. The species is essentially univoltine throughout most of its range with a single mid-summer flight from the end 

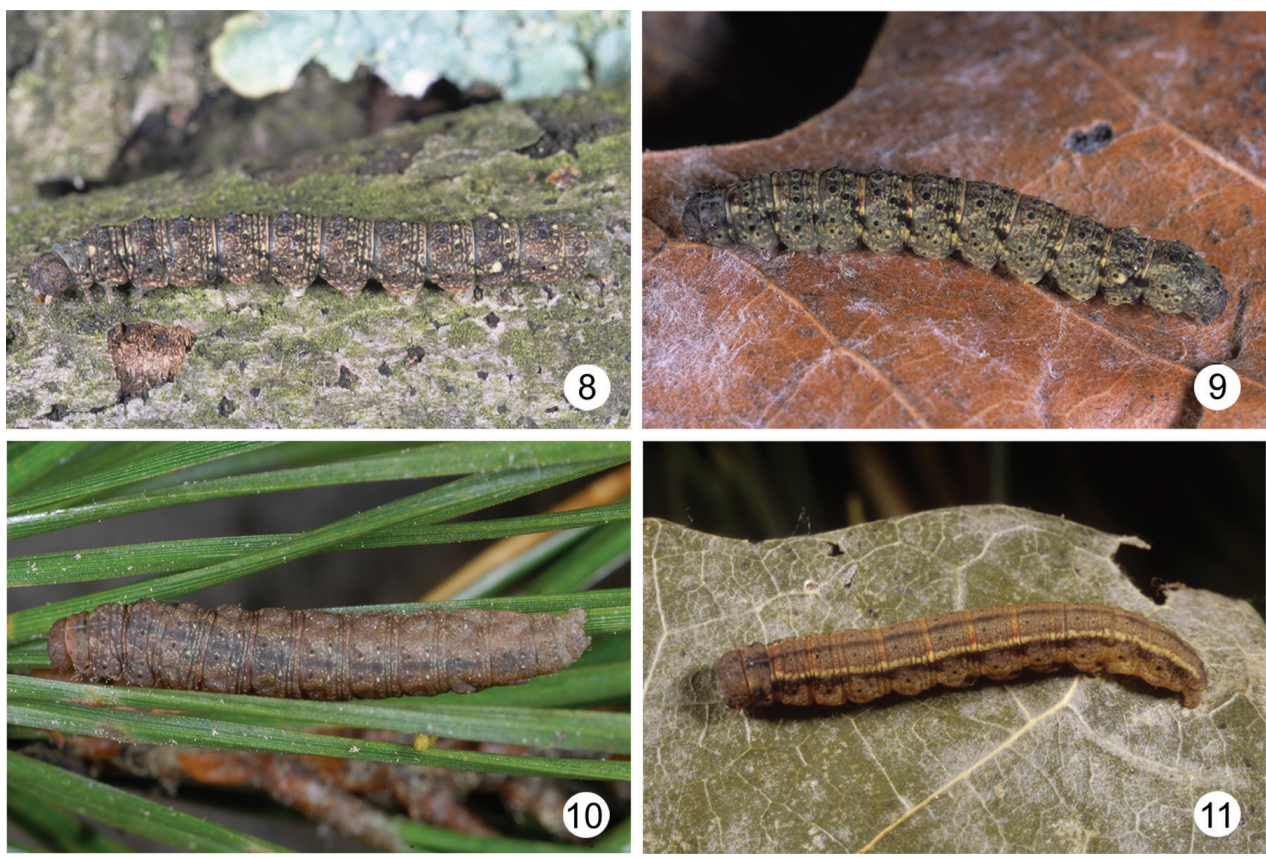

Figures 8-I I. Last instar Zanclognatha. 8 Z. dentata sp. n.: NC: Haywood Co., Great Smoky Mountain National Park, Catalochee Campground, DLW Lot 2002E83, larva and photo 10 June 2002. 9 Z. dentata sp. n.: NJ: Atlantic Co., Egg Harbor Township, Abescon Creek, female (mother) 15 July 2002; photo: 24 August 2002, DLW Lot 2002G117 I0 Z. martha. NY: Clinton Co., Clintonville, Dry Bridge Road, N44²28'14", W73³6'15", 660ft, larva 25 June, 2008, on Pinus rigida, DLW Lot 2008F200 I I Z. protumnusalis. CT: New London Co., Griswold, Hopeville Pond State Park, female 10 August, 1997, image November 1997, Fred Hohn lot number F263.

of June through early August, with more than $80 \%$ of the adults from New Jersey northward taken in July. Records from early September in western North Carolina and northern Georgia by James Adams (pers. comm.) are indicative of a small second brood, as also occurs in Z. protumnusalis and others (Wagner et al. 2011).

Chris Maier, Jeff Fengler, and Carol Lemmon, made numerous collections of $Z$. dentata during their survey of conifer-feeding caterpillars of the Northeastern United States (Maier et al. 2004). Nine of their larval collections were reared to the adult stage; larval images for four additional collections are assignable to $Z$. dentata. Their host records include: Abies balsamea (L.) Mill. ( $\mathrm{n}=7)$, Tsuga canadensis (L.) Carrière ( $\mathrm{n}=3)$, and Pseudotsuga menziesii (Mirb.) Franco. We have taken singleton larvae in beating sheet samples on three occasions: from Hamamelis virginiana L., Lonicera morrowii A. Gray, and a third, unrecorded host. All of the above were taken in May and June as penultimate or final instars. Although Zanclognatha species are generally regarded to be litter dwellers (Crumb 1956; Hohn and Wagner 2000; Wagner 2005), at least three other members of the genus (in addition to $Z$. dentata) are known to feed above the ground: $Z$. theralis (Walker, 1859) in Usnea lichens (Sigal 1984); Z. protumnusalis in fir, spruce, pines, and other conifers (Prentice 1962 and reared specimens in the PMNH); and $Z$. 
martha a hard pine associate (Wagner et al. 2011). We also have taken Zanclognatha cruralis (Guenée, 1854) and related species on occasion while beating low woody and herbaceous vegetation in forests, but mostly in the fall, before leaf fall, and not in the spring as has been the case with the four Zanclognatha listed above. Dale Schweitzer and DLW reared an ex ova cohort of $Z$. dentata through to maturity on a diet of dead oak leaves (DLW Lot 2002G117).

\section{Larval Identification}

The caterpillar is mottled in brown, red, and yellow with a conspicuous pale subdorsal spot on A7 (Figs 8-9). Below we expand Crumb's (1956) key to Zanclognatha larvae by including four new taxa: $Z$. dentata, $Z$. martha, $Z$. protumnusalis, and $Z$. marcidilinea (Grote, 1872). Given the confusing taxonomy of the genus (e.g., the possibility of misidentifications, especially in historic material), our small sample sizes, intraspecific (including ontogenetic) variability in larval phenotypes, our key should be considered preliminary. Development of the middorsal stripe, emphasized by Crumb (1956) and below, is variable. For example, our example of $Z$. marcidilinea had only a weak line, best expressed over the thoracic segments; conversely $Z$. cruralis sometime has the remnants of a middorsal line (broken between segments). Last instars of all ten species are figured in Wagner et al. (2011).

\section{Preliminary key to Zanclognatha larvae}

1 Ground color smoky to charcoal; body somewhat corrugated (constricted between segments); red reticulations inconspicuous; larva arboreal on pitch and perhaps other hard pines

- Ground color with variously developed red reticulations at least laterally and otherwise not as above ................................................................. 2

2 Middorsal stripe usually present over abdomen; ground colors various........ 3

- $\quad$ Middorsal stripe usually absent over abdomen; ground color with conspicu-

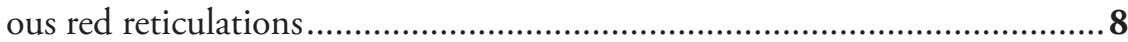

3 Middorsal stripe fuscous (dark), contrasting with adjacent dorsal coloration

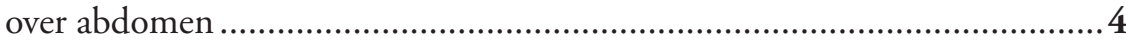
Middorsal stripe reddish, weakly contrasting with adjacent dorsal coloration, evident mostly over thorax .........................................................6

4 Dorsum with red mottling that often joins into lines along inner side of creamy subdorsal stripe

Z. protumnusalis

- $\quad$ Not as above; mottling not coalescing into red lines and without a creamy subdorsal stripe; dorsal area reticulated in gray, brown, red, and yellow...... 5 
5 Ground color smoky; dorsal pinacula over abdomen slightly enlarged, diameter > than height of spiracle on A8; diffuse, dark oblique lines extending forward and upward from spiracle, especially on A2-A6 (A7) ...Z. pedipilalis

- $\quad$ Ground color reddish; dorsal pinacula over abdomen slightly enlarged, diameter < than height of spiracle on A8; without set of well-developed, dark oblique lines extending forward and upward from spiracle, especially on A2A6.

Z. laevigata

$6 \quad$ A7 with pale supraspiracular spot

7

A7 without pale supraspiracular spot; often with oblique, arching yellow line, between dorsal pinacula on A1-A7.

Z. marcidilinea

7 Dorsal abdominal pinacula wartlike, conspicuously wider and higher than those over thoracic segment, diameters > height of A8 spiracle; pale spot on A7 from (raised) supraspiracular swelling (bearing SD1).... Z. dentata sp. n.

- Dorsal abdominal pinacula flatter, diameters similar to those over thoracic segments, < height of A8 spiracle; subdorsal area of A7 not conspicuously swollen

Z. lituralis

Dorsal abdominal pinacula small; diameters equal to those over thoracic segment and diameter < height of A8 spiracle....

Z. theralis

- $\quad$ Dorsal abdominal pinacula distinctly larger than those over thorax, diameters $\geq$ height of A8 spiracle.

Dorsal abdominal pinacula enlarged but diameter of D1 pinacula $<1 / 4$ distance that separates them across midline; D1 pinaculum $<2 \times$ diameter of D2 pinaculum

- $\quad$ Dorsal abdominal pinacula larger with diameter of D1 pinacula about 1/3 distance of that separating them across midline; D1 pinaculum $>2 \times$ that of D2 pinaculum Z. jaccusalis ( $=$ Z. ochreipennis of Crumb 1956)

10 D1 and D2 pinacula over abdominal segments subequal; southern US

Z. obscuripennis

- $\quad$ Diameters of D1 pinacula larger than those of D2 over abdominal segments; widespread (common)

Z. cruralis

\section{Discussion}

Zanclognatha dentata is widespread in Northeastern North America. In most collections it is intermixed with Zanclognatha protumnusalis. Less often specimens are sorted with those of $Z$. lituralis and $Z$. martha. Surprisingly, given the number of wing scaling characters that distinguish $Z$. dentata from other Zanclognatha, we did not find male or female genitalic differences that would reliably separate the new species from $Z$. protumnusalis. As noted above, genitalia are somewhat generalized across the genus (see Forbes 1954: 389 for illustrations of the valve and aedeagus for seven species). As 
is suggested by the larval key, all of the aforementioned species of Zanclognatha, and others, can be distinguished based on larval characters (see also Crumb 1956).

Daniel Handfield had individuals of both $Z$. protumnusalis $(\mathrm{n}=37)$ and $Z$. dentata $(\mathrm{n}=31)$ from Quebec sequenced as part of the Bar Codes of Life Data System (http:// www.barcodinglife.org/views/login.php). His $Z$. dentata (included as paratypes here) clustered in two haplotype groups, remote from those of $Z$. protumnusalis which clustered in a single group that included several haplotypes. In a larger Zanclognatha data set $(n=251)$ that includes barcodes of all named eastern species, most $Z$. protumnusalis clustered with $Z$. cruralis, Z. jaccusalis (Walker, 1859) and Z. obscuripennis (Grote, 1872), whereas $Z$. dentata haplotypes clustered with $Z$. martha, $Z$. theralis (Walker, 1859) (in part) and $A$. atrilineella (Grote, 1873) (Don Lafontaine in litt.). That the two species were not each other's sisters is hardly surprising given the differences in larval phenotypes of the two: compare figures 8 and 9 with 11 and differences enumerated in the larval key.

The type of Zanclognatha minimalis Grote, 1878, currently regarded as a synonym of $Z$. protumnusalis (e.g., Franclemont and Todd 1983) (BMNH), is somewhat intermediate in character between $Z$. dentata and $Z$. protumnusalis. On the whole $Z$. minimalis aligns best with the latter, e.g., hindwings of $Z$. minimalis are too pale to fit comfortably within $Z$. dentata and the discal spot is small, round and almost free of dark scales. However, two features of the type give us pause: (1) the postmedial line is strongly expressed to the inner margin (it is nearly always vague below the cell in $Z$. protumnusalis). (2) Likewise the antemedial line is toothed and well expressed to the inner margin, and thus more reminiscent of Z. dentata.

The New York State Museum has no historical records of Zanclognatha dentata, and TLM did not find this species in Ithaca when he collected there at both light and bait from 1974-1975. The earliest specimens that we have been able to locate are a series in the American Museum of Natural History from Ocean County, New Jersey taken in 1936. And while the recency of discovery of what is now a widespread and common moth would suggest the species could be an introduction, its presence in northern bogs in Quebec, barrens in New Jersey (in the 1930s), and cove forests in the Great Smokies Mountains are indicative that $Z$. dentata is a native that escaped the attentions of early lepidopterists.

Zanclognatha is in need of revisionary study. The number of valid species in the gypsalis-theralis-deceptricalis-inconspiculis complex is unknown. Zanclognatha lituralis consists of at least two valid species (Rings et al. 1992). We are uncertain if what is being called Zanclognatha martha in the Great Lakes Region is conspecific with the pitch pine-feeding populations of the Eastern seaboard states. Likewise, $Z$. protumnusalis (even with $Z$. dentata removed) may not be a single entity, e.g., specimens from along the Gulf Coast may be nominally distinct. COI barcodes and other (nuclear) molecular data will be needed in many cases, as both genitalia and wing patterns are often of limited utility in the genus. Larvae of Zanclognatha are diverse in character given the modest differences in adult features (Zanclognatha dentata was initially recognized as 
a distinct entity based on its larva). We encourage others to rear ex ova broods and to preserve and photograph larvae as circumstances permit-most Zanclognatha can be reared on dead oak, cherry, and birch leaves.

\section{Acknowledgments}

Don Lafontaine and Hugo Kons made important suggestions on earlier versions of the manuscript, shared COI trees, supplied unpublished information on the genus Zanclognatha, and sent images which were helpful to our effort. Chris Maier provided unpublished host data and allowed us access to larval images that resulted from his multi-year survey of conifer-feeding Lepidoptera. Gareth Edward King edited a draft of the manuscript. Martin Honey and Don Lafontaine sent images of the types of Zanclognatha minimalis and $Z$. protumnusalis from the Natural History Museum. James Vargo and James Adams sent images and notes for the specimens they collected in the Upper Midwest and Appalachians, respectively. Others supplying phenological and distributional information include George Balogh, Hugh McGuinness, Mark Mello, and J. Bolling Sullivan. We also thank Larry Gall and Ray Pupedis for arranging the loan of specimens in the Peabody Museum. Shawn Binns formatted the paratype data and an early draft of the manuscript. An anonymous reviewer made several helpful suggestions on the initial submission. Amy Fernald prepared the plates. Support for this work has been partially funded by the Connecticut Department of Energy and Environmental Protection's State Wildlife grant program (to DLW) and New York State Wildlife Grant T-17 (to TLM).

\section{References}

Crumb SE (1956) The Larvae of the Phalaenidae. Technical Bulletin 1135. USDA, Washington, DC, $356 \mathrm{pp}$.

Forbes WTM (1954) The Lepidoptera of New York and Neighboring States. III. Noctuidae. Memoir 329. Cornell University Agricultural Experiment Station, Ithaca, New York, $433 \mathrm{pp}$.

Franclemont JG, Todd EL (1983) Noctuidae, pp. 120-159. In: Hodges RW et al. (Ed) Check List of the Lepidoptera of America North of Mexico, E.W. Classey Ltd. and The Wedge Entomological Research Foundation, Cambridge Univ. Press, Cambridge, United Kingdom.

Hohn FM, Wagner DL (2000) Larval substrates of herminiine noctuids (Lepidoptera), macrodecomposers of leaf litter. Environmental Entomology 29: 207-212. doi: 10.1603/0046-225X(2000)029[0207:LSOHNL]2.0.CO;2

Lederer J (1857) Die Noctuinen Europa's, mit zuziehung einger bisher meist dazu gezahlter Arten des Asiatischen Russland's, Kleinasien's, Syrien's, und Labrador's. Friedrich Manz, Vienna, 251 pp, 4 pls. 
Maier CT, Lemmon CR, Fengler JM, Schweitzer DF, Reardon RC (2004) Caterpillars on the Foliage of Conifers in the Northeastern United States. USFS Technology Transfer Bulletin, FHTET-02-06. USDA Forest Service, Morgantown, West Virginia, 151 pp.

Owada M (1987) A taxonomic study on the subfamily Herminiinae of Japan (Lepidoptera, Noctuidae). National Science Museum, Tokyo, 208 pp.

Poole RW (1989) Lepidopterorum Catalogus (New Series). Fascicle 118 Noctuidae, Parts 1-3: xii $+1-1314$. E.J. Brill, New York, 1314 pp.

Poole RW, Lewis RE (1996) Nomina Insecta Nearctica. A Check List of the Insects of North America. Volume 3: Diptera, Lepidoptera, Siphonaptera. Entomological Information Services, Rockville, Maryland, 1143 pp.

Prentice RM (compiler) (1962) Forest Lepidoptera of Canada Recorded by the Forest Insect Survey. Vol. 2, Nycteolidae, Notodontidae, Noctuidae, Liparidae. Forest Entomology and Pathology Branch Bulletin 128: 77-281.

Rings RW, Metzler EH, Arnold FJ, Harris DH (1992) The Owlet Moths of Ohio (Order Lepidoptera: Family Noctuidae). Ohio Biological Survey Bulletin. New Series. Vol. 9, College of Biological Sciences, Ohio State University, Columbus, Ohio, 219 pp.

Schrank FP (1802) Fauna Boica. Durchgedachte geschichte der in Baiern Einheimischen un Zahmen Thiere. Zweyter Band. Zweyte Abthilungen. J. W. Krüll, Ingolstadt, Germany, 161.

Sigal LL (1984) Of lichens and lepidopterons. The Bryologist 87: 66-68. doi: 10.2307/3242884

Smith JB (1895) Contribution toward a monograph of the insects of the lepidopterous family Noctuidae of boreal North America - a revision of the deltoid moths. Bulletin of the United States National Museum 48: 129 pp, 14 pls.

Wagner DL (2005) Caterpillars of Eastern North America: A Guide to Identification and Natural History. Princeton University Press, Princeton, New Jersey, 512 pp.

Wagner DL, Schweitzer DF, Sullivan JB, Reardon RC (2011) Owlet Caterpillars of Eastern North America (Lepidoptera: Noctuidae). Princeton University Press, Princeton, New Jersey, $576 \mathrm{pp}$. 